\title{
Human geography and questions for social work education
}

\section{Pat Wilkinson $^{1} \&$ Gavin Bissell ${ }^{2}$}

Summary: Despite a sometimes implied lead, in the social work literature, of social work training over health training in the area of values, since the decline of community social work in the 1980s health training has developed a focus upon the physical environment which seems set to leave social work education trailing behind in the area. This paper therefore explores inter - professional overlap in the area of human geography, and in particular its relation to professional identity and the core social work value of social responsibility. Finally, it outlines ways of raising awareness of the physical environment among social work students, and in doing so seeks to break free of the placement/learning environment dichotomy and link social responsibility to the campus experience itself.

Keywords: human geography; space; placement learning; social work education; environment

1.Head of Department and Senior University Teacher

2. University Teacher

Address for Correspondence: Gavin Bissell, Dept of Social Sciences and Humanities, University of Bradford, Bradford BD7 1DP, UK. g.bissell@bradford.ac.uk 


\section{Introduction}

A popular phrase in the social sciences in the 1990s was 'space makes a difference', as the regionally varied impact of economic and structural change in Britain during that period was investigated. Although there was no agreement upon exactly what difference it did make, the impact that the localities debate had upon sociology, cultural studies, and health studies in the 1980s and 1990s was notable (Giddens, 1984; Urry, 1985; Peet \& Thrift, 1989; Duncan, 1989; Paasi, 1991; Jackson, 1991; Sayer, 1991; Duncan \& Savage, 1991), and spatial concepts now seem to occupy a modest but permanent place in these areas (Phillipson, 2007; Popay et al, 2003; Gillespie, 2002; Andrews, 2006). There are even signs of a renewal of interest in recent years (Duncan, 2002).

Yet the impact of this 'geographical turn' upon social work has been more muted, and this is especially true of human geography, which concerns itself primarily with perceptions of place. The purpose of this paper is therefore to explore one small aspect of the relationship between social work and place, and that is its role in practice learning. In fact the regulating body of social work requires that the placement be a 'conducive physical environment', and of course this means more than merely being a 'safe' place: is it for example experienced as a place conducive to learning? Does the student feel at home, or uneasy, at the placement agency? More to the point perhaps, do service users? This is the area we are looking at.

Fortunately we can draw upon parallel initiatives in doing this. Lessons can be learned from Health Studies (see Curtis \& Rees-Jones, 1998 for a useful summary), from the HEFCE Sustainability in Education agenda, and from existing techniques in geography education.

\section{The campus and social work values}

We want to start by looking at what the universities' sustainability agenda can contribute to this area, and then move on to the contribution of Health Studies.

It is now accepted that the geography of the university campus will play an important role in inculcating the values of environmental responsibility in the next generation of graduates (Martin \& Wheeler,

56 Journal of Practice Teaching \& Learning 7(2) 2006-07, pp.55-68. () 2007 Whiting \& Birch Ltd 
1975; Bahro, 1986; Cahill, 2002). What is much less certain, however, is how the equally important values of social responsibility are to be passed on to the next generation. That goal was, in fact, one legacy of the early - twentieth - century University Settlement Movement, the proponents of which, Jane Addams, Patrick Geddes and others, are often seen as involved in the early history of social work in Britain and America (Addams, 1910/1967; Geddes, 1915/1968). Their envisioned method of inculcating social responsibility, the summum bonum of student houses sited in the community, has faded. Where to now?

The question is more pressing than it might at first appear. A third of students now remain living at home for the duration of their degrees, and because of this many will miss altogether the important and often formative experience of being a new arrival in an unfamiliar area. Even those who do in growing numbers swell the student cohorts of distant city universities, however, will probably begin and perhaps spend their study years elsewhere than in the formative melange of a student house squeezed between terraced family homes. Instead, they will as likely as not find themselves cocooned in secure and comparatively luxurious study bedrooms, removed from the streets and environment that Jane Addams and Patrick Geddes saw as so essential to the development of social responsibility (Addams, 1910/1967; Geddes, 1915/1968).

In this paper, other ramifications of the situation will be explored, and some possible ways forward identified.

\section{Consequences of the student ghetto}

This should not be read as a nostalgic piece about better times, since a system of privileged access for a minority but funded by all could hardly command general respect in the present political climate. Yet there are senses in which the present arrangement does not necessarily appear more democratic. For example, the heterogenizing intentions of the University Settlement Movement were partly realized insofar as some class permeability occurred in Settlement areas, and partly realized later in the areas in which students lodged amongst diverse groups (Addams, 1910/1967; Geddes, 1915/1968). With the increasing creation of whole areas exclusively populated by young students, however, it is possible to find students turning away from other groups and associating exclusively

57 Journal of Practice Teaching \& Learning 7(2) 2006-07, pp.55-68. @ 2007 Whiting \& Birch Ltd 
with one another. At the same time, the absence of other groups such as buggy-pushers and long-term residents leaves students little concerned about street refuse, poor pavements and building sites. Diverse groups such as new arrivals, older people, and those with disabilities, will have (been) removed to other sites.

Geddes (1915/1968) also felt strongly that travel should be a learning event, perhaps at its best in the daily walk or bus ride, and here again experiences will be diverse.

It might be objected that we have no clear idea of what a campus environment that inculcates social responsibility would look like. We do have some fairly well established clues, however. Sommer (1974) observed the individualizing construction of new university campuses in America in the 1960s, with their fixed forward-facing lecture room seating, their concentration on individual study facilities, their alienating architecture, and their often remote campus location which tends to encourage dispersion and departure after $4 \mathrm{pm}$ for staff and many students. These findings, taken together with Addams' (1910/1967) Settlement Movement ideals, suggest the following. The 'socially responsible' campus should be outward-looking, non-individualizing, co-operative and anti-oppressive, and should involve students, staff and others in the life of the university. It can, and most universities do, achieve this to a varying extent by existing strategies. For example, theatres, galleries, some libraries, gymnasia, swimming pools, refectories and even bars on campus have guest access or better, and taken together with concerts, school visits, sports events, conferences and fixed ceremonies, they ensure that universities are outward-looking to at least some extent, although there is arguably a class basis to community participation in educational institution informal activities ( Bagnall et al., 2003).

However, the 'socially responsible' campus must link students up to whatever community involvement it has, as well as engaging students in the life of the university, and this is not straightforward, as Sommer (1974) found.

From the point of view of social work training, we could draw in the travel-to - campus experience, draw in the ongoing job-based experience of undergraduates, and make more of course representatives and other forms of student involvement.

Summarizing, student involvement issues are geographical issues, as well as social ones, partly because the human geography of the campus is not always conducive to collective projects and to engagement.

58 Journal of Practice Teaching \& Learning 7(2) 2006-07, pp.55-68. @ 2007 Whiting E Birch Ltd 


\section{Placements as a site for the inculcation of social responsibility}

It might well be objected that the social work placement now furnishes the physical environment in which the student encounters the service user more or less against the physical backdrop of the service user's own territory. There are at least two significant problems with this view.

Firstly, the view sets up an implicit opposition between a neutral learning environment in the university, on one hand, and the physical environment of social work beyond the campus wall, on the other. However, Sommer's (1974) 'new campus' research in the 1970s led him to infer that the perception of a neutral learning environment on university campuses resulted from the desensitization of individuals to their environment, rather than neutrality per se. The notion of 'unconscious' use of space in a campus context was further developed by Lym (1980) with the distinction between 'acute' and 'chronic' experiences of space, with 'chronic' experience of space implying an unreflecting or even indifferent movement between locations.

Secondly, the 'placement encounter' view of place awareness presupposes that the physical environment of social work is in fact detected in a meaningful way: that it involves an 'acute' experience of space, to put it in Lym's (1980) terms. Yet we will have to divert our attention to Health Service training to get some idea of what we are looking for here.

\section{Health and the environment}

The Black Report (1981) linked health outcomes to social class, and in the Nineteen - Eighties this was taken on board in community work and to an extent in social work. In the late 1980s a revival of interest in health and the environment took place, but this renewed interest in the environment seems not to have had quite the same impact in social work as it has in Health Studies. Why not? One reason may be that social work seemed to have substituted the rather abstract notion of the 'community', in the form of The NHS and Community Care Act (1990), for the real physical environment of local streets and buildings. The

59 Journal of Practice Teaching \& Learning 7(2) 2006-07, pp.55-68. @ 2007 Whiting \& Birch Ltd 
result is that the physical environment increasingly appears as a virtual entity in social work. Moreover, social work seems to have by-passed the debate in the social sciences in the 1980s, in which the fruitful but arguably static and otherwise problematic geographical concepts embodied in Community Studies in the 1970s were transformed, in the 1980s, first into Locality Studies and then into complex conceptions of culture, place, and Habitus (Massey \& Jess, 1995).

At the same time, and in marked contrast, health trusts have implemented community development programs over the same period which have highlighted the relevance of the physical environment (Plant $\&$ McFeely, 2004). Perhaps symptomatically, the Journal Health \& Place, which began in 1995, appears to have no social work equivalent, and the teaching model used in nurse education seems to take the physical environment of nursing students themselves into consideration, even to the extent of supervising their general living conditions (Abbatt $\&$ McMahon, 1985). When it comes to the outcome of training, Healy et al. (2003) have identified what appear to be significant differences in the environmental awareness of Nurses, Social Workers, and Occupational Therapists, with the latter seeming to show the greatest awareness of the physical environment when making hospital discharge arrangements. The NHS, furthermore, appears to be funding research into its own organizational environment (Halford \& Leonard, 2005). However we interpret their findings, they do seem to suggest that the health care approach possesses important advantages in this area.

\section{Social work and the environment}

Social work does have a geographical tradition, but it seems much more tentative, provisional and scattered (Gutheil, 1992; Resnick \& Jaffee, 1982; Germain, 1978; Phillipson, 2007). This is particularly interesting if somewhat ironical in view of the perceived inclusiveness and flexibility of the social work knowledge base.

Indeed, social workers are perceived by health colleagues, according to health - originated research findings, as having a fuzzy knowledge base and therefore some uncertainty regarding their professional identity and their role in multi-disciplinary teams, which in turn is seen to lead to lower levels of professional confidence and uncertainty in dealing

60 Journal of Practice Teaching E Learning 7(2) 2006-07, pp.55-68. (C) 2007 Whiting \& Birch Ltd 
with patients (Carpenter et al, 2003).

Conversely, social workers tend to see their health colleagues as sometimes placing too much confidence in a putative 'medical model' and consequently 'knowing what is best' for individual service users (Bircher, 2000; Oliver \& Sapey, 1999). They point to the provisional and apparently changing nature of the health advice given out by community medicine practitioners as evidence of the misplaced confidence of health colleagues, and more recently they question the power of the Pharmaceutical industry and its role in the determination of medical practice with service users (Green, 1982; Phillipson, 1989; Law, 2006). Finally, Social workers have an incipient fear that their job is being taken over by the medical model (Carey, 2003; Butler \& Drakeford, 2005).

Despite the picture of professional divergence which this suggests, however, we want to argue that there are potential gains for social work in the encounter between social work and health care, and that a key positive is the attention given to the person-environment relation. The question then is: how can social workers overcome the professional reluctance to focus upon the environment, tied as it is to our perception of ourselves as primarily workers with human relationships? More precisely, how can such a change be developed in the classroom?

\section{Pedagogic methods for raising awareness of the social work placement environment}

This section of the paper is about level of awareness, and students' ability to relate perceptions of the campus to social work issues and to the placement.

An earlier study with 20 MA Social Work students found relatively low levels of awareness of placement geography issues (Wilkinson \& Bissell, 2005). The problem seemed to be that those students who already had an awareness of placement geography answered questions about it comprehensively, but these students were a tiny minority. The problem therefore seemed to be that students' awareness of placement geography depended upon the individual student being sensitive to geographical features prior to the start of the placement. If they didn't have this, we found, there was little to be gained by engaging them in exercises and discussions about the physical features of the placement

61 Journal of Practice Teaching \& Learning 7(2) 2006-07, pp.55-68. @ 2007 Whiting \& Birch Ltd 
either during or following completion of the placement. We therefore conjectured that it was necessary to raise student awareness of aspects of the physical environment-principally issues of risk, oppression, and identity-before they went out on placement. It should then be possible to engage students in discussion of these aspects of their placement during and after the placement experience. The problem at this stage was that of how to raise awareness of appropriate aspects of the physical environment. Any training exercise had to involve all 66 students in discussion.

There are several techniques in the literature on environmental education, with approaches such as (preparing and participating in) town trails and guided urban walks (Martin \& Wheeler, 1975). It is interesting to note in this connection that Birmingham University social work students as long ago as the 1960's were boarded onto coaches and escorted around deprived areas of the city as part of their induction.

The campus experience seemed an obvious place experience common to all of us (though there were others), and this formed the subject of the first exercise. Fortunately there was a social work literature to draw upon at this point (Adams, Geddes), and we were also able to connect with recent work upon the relation between the pedagogic physical environment and the inculcation of ethics (Bahro, 1986), some of it emerging from the Ecoversity project at Bradford University.

\section{The Ecoversity project}

The Ecoversity project at Bradford University is based upon the notion that if sustainable and environment-conscious features are part of the campus environment then this will help to produce graduates who are similarly aware. There is currently a competition to see who can come up with the best design for a new 500-bed green student village on the campus, and one issue will be whether students will actually prefer private luxury single study flats to collective environmentally-conscious student houses.

From the point of view of training social workers, if we can use a physical environment to inculcate environmental responsibility, then we can also use it to promote social responsibility, on the reasonable expectation that once stimulated the sense of responsibility can

62 Journal of Practice Teaching \& Learning 7(2) 2006-07, pp.55-68. () 2007 Whiting \& Birch Ltd 
be extended. But social responsibility is inextricably linked with environmental responsibility anyway: it may be of limited effect to ask a disadvantaged person to prioritize ecologically sound waste disposal and consumption while accommodation, unemployment, family needs or debt are immediate concerns.

We acknowledge, too, that if social workers are to be trained in environmental perception then they may also need to be assessed in it, which may add to the agenda of training offered to practice educators and others. But does this necessarily move us away from the National Occupational Standards-led breakdown of the social work role? Arguably not: indeed the values, for example, only fully make sense insofar as they are applied to social work with people in specific physical environments. As Duncan (1991) has pointed out, social relations do not exist 'on the head of a pin'. A more extensive analysis of the relation of human geography to the NOPS key roles and values, however, is beyond the scope of the present article.

\section{The Campus exercise}

The pre-placement students were given an A3-sized map of the University campus, and invited to identify on the map places about which they had various kinds of feelings. This exercise is based upon a spatial awareness-raising map exercise used by Stea (1976) with schoolchildren. Stea (1976) noted incidentally that adults typically have lower levels of spatial awareness than children.

We then hoped to carry out a similar exercise around the same students' placement experiences, once these were underway. This part of the study is still in progress: overall, we hope it will raise student awareness of placement human geography, and with it awareness of the impact of the physical environment of welfare agencies upon service users.

There were some interesting initial findings with the map exercise, however, which are worth summarizing briefly here, since they shed a little light on the place awareness of a cohort of first year social work students.

When asked to identify places on the campus they tended to avoid, students identified: the nearby college entrance; the student common

63 Journal of Practice Teaching \& Learning 7(2) 2006-07, pp.55-68. (C 2007 Whiting \& Birch Ltd 
room, which they perceived to be used by students from non-social work degree pathways and/or students from the college; areas of the campus, such as behind the sports hall, frequented by students from other faculties (for example computer studies students, rightly or wrongly perceived to have a 'laddish' culture oriented to 'male' interests such as football or cars), or by college students; or by non-students.

These three experiences were widespread, and seemed to be more about social class than anything else, although gender may have been an involved factor. They seemed not to be about ethnicity.

Some students identified one particular corner of the campus as a place they avoided late at night. When questioned further, they said that this was where students from two separate halls of residence clashed when going to and from the students' union on the campus. Geographically, it was the point at which the pathways merged. One hall was off-campus. The apparent place-identities of these two groups of students are very interesting, and worth further study.

When asked to identify a place where they went for privacy and quiet study, many students identified a coffee bar on the campus, and also the refectory, and the usually sunny Atrium. It is interesting that they did not identify the library, in view of the fact that library architecture is specifically designed to promote privacy (Sommer, 1974). This finding is however consistent with Lym's (1980) findings, which highlighted the social usage of university libraries.

Conversely, when asked to identify a place where they felt most relaxed and safe, most students identified the library. Arguably, this fits in well with research done on identity and place: the library is perhaps the place where students get most confirmation of their identity, and therefore feel most secure and relaxed (Relph, 1976).

Interestingly, students identified a variety of places they went to at lunchtime, including a bar area and outside bar area on the campus, even though they did not go there to drink alcohol. The outside bar area was of interest to smokers, but also to others. Also, some students clearly ate their lunch in the library, even though it was against regulations, and went there with their friends, suggesting that it was an important social location too.

So far, the responses and explanations given by students in class support the view that users' perceptions of a place do not necessarily coincide with its ostensible purpose, and this is an important, if obvious, message for students to take with them to their placement agencies

64 Journal of Practice Teaching \& Learning 7(2) 2006-07, pp.55-68. () 2007 Whiting \& Birch Ltd 
(Taylor, 1974).

Generally, students tended to identify areas well - in on the campus as safe relaxed places where they felt at home or had their lunch, and opted to see the edges of the campus or just outside it as places that they tend to avoid. There were exceptions: one student identified no less than seven places as lunch locations (including a car park and a grass bank), apparently having a well-developed sense of place where food was concerned.

This avoidance of the immediate environs of the campus among first-year undergraduates may be nothing more than the inward-looking nature of the university as a psychological entity (Sommer, 1974). However, in the case of social work students, it perhaps feeds into the implicit opposition between welfare placement on one hand and neutral learning environment on the other, described earlier as an implicit feature of social work training courses.

Some methodological questions present themselves at this point. It is assumed that all students can read the map: they have after all been using it to locate classrooms for most of the year, presumably. It might be objected that spatial experience is three-dimensional, whilst the mapping exercise is two dimensional. It has been pointed out by Campbell (1994) that primary experience of place is in fact two-dimensional, and that individual orientation to place is not within 'absolute' space, but in relation to the 'slope' of a place or its primary directionality for the individual. The questions about purpose ('Where would you go for privacy..') key in to this directionality or slope. These questions around the application of concepts lead to the larger question of the under-use of human geography in social work and whether or not this arises from the use of interpretive methods. There is current debate in the human geography literature itself about the apparently marginal status of this discipline and the reasons for it (Cameron, 2005). On one hand, it is seen to preoccupy itself with abstract and 'irrelevant' issues, whilst on the other, it is perceived to be naive in its apparently uncritical acceptance of such politically loaded concepts as 'underclass' Cameron, 2005). Do these problems arise from the interpretive nature of human geography, however, and is Human Geography to be avoided by social work researchers because it is interpretive in nature? This does not appear to have been an obstacle to the 'interpretive turn' in, for example, the critical criminology of the 1970's, and Ward (1973) seemed to acknowledge a potential role for human geography in that area at

65 Journal of Practice Teaching \& Learning 7(2) 2006-07, pp.55-68. @ 2007 Whiting \& Birch Ltd 
that time. Or is it that geography itself continues to be tacitly thought insufficiently critical for social work research purposes (Hurst, 1985)?

\section{Conclusion}

The overall argument of this paper can be summed up as follows. The social work literature identifies a diverse corpus of theories - in tension - as its knowledge base, and sees this as an asset, distancing itself from what it takes to be the orthodoxy of medical scientism. Despite this diversity in the knowledge base, however, the opportunity to engage with the study of the physical environment of social work, and of social work education, has not been fully grasped. The campus environment of social work education may provide an opportunity to develop social work students' missing awareness of the physical environment, an awareness which can then be carried forward to social work placements, with potential benefits for service users. In this regard, the specific initiative of the Ecoversity may offer a unique conjunction at which to engage students' attention with the campus physical milieu, reconnecting social work education with its earlier traditions of the Settlement Movement and community engagement.

\section{References}

Abbatt, F. and McMahon, R. (1985) Teaching Health Care Workers. A practical guide. London. Macmillan

Addams, J. (1967) Twenty Years at Hull House. New York: Macmillan. (Original edition, 1910)

Andrews, G. (2006) Geographies of health in nursing. Health E Place, 12, 1, 110-118

Bagnall, G., Longhurst, B., and Savage,M. (2003) Children, belonging and social capital: the PTA and middle class narratives of social involvement in the North West of England. Sociological Research Online, 8, 4

Bahro, R. (1986). Building The Green Movement. London: GMP

Bircher, G. (2000) Disabled people, health professionals. Disability E Society, $15,5,775-783$

66 Journal of Practice Teaching \& Learning 7(2) 2006-07, pp.55-68. () 2007 Whiting \& Birch Ltd 
Cahill, M. 2002. Environment and Welfare: Towards a green social policy. Basingstoke: Palgrave Macmillan

Cameron, A. (2005) Geographies of welfare and exclusion: Initial report. Progress in Human Geography 29, 2, 194-203

Campbell, J. (1994) Past, Space, and Self. London. MIT Press

Carey, M. (2002) Anatomy of a care manager.Work, Employment and Society, $17,1,121-135$

Carpenter, J., Schneider, J., Brandon, T., and Wooff, D. (2003) Working in multidisciplinary community mental health teams: The impact on social workers and health professionals of integrated mental health care. British Journal of Social Work, 33, 8, 1081-1103

Curtis, S. \& Rees-Jones, (1998) Is there a place for geography in the analysis of health inequality? in M. Bartley, D. Blane, and G.D. Smith (Eds.) The Sociology Of Health Inequalities. Oxford: Blackwell

Duncan, S. (1989) What is locality? in R. Peet and N. Thrift (Eds.) New Models In Geography. Vol.2. London: Unwin Hyman (pp.221-252)

Duncan, S. and Savage, M. (1991) New perspectives on the locality debate. Environment and Planning A., 23, 2, 155-164

Duncan, S. (2002) Space, Localities and Social Policy. Unpublished paper. University of Bradford Department of Social Sciences and Humanities

Geddes, P. (1968) Cities In Evolution. An introduction to the town planning movement and to the study of cities. London: Ernest Benn (Original edition, 1915)

Giddens, A. (1984) The Constitution Of Society. Cambridge: Polity

Gillespie, R. (2002) Architecture and power: A family planning clinic as a case study. Health \& Place, 8, 3, 211-220

Green, B. (1982) Structural antecedents of psychoactive drug use among the elderly. Ageing and Society 2, 1, 77-94

Halford, S. \& Leonard, P. (2006) Place, space and time: contextualizing workplace subjectivities. Organization Studies 27, 5, 657-676

Healy, J., Victor, C., Thomas, A., and Seargeant, J. (2003) Professionals and post-hospital care for older people. Journal of Interprofessional Care, 16, 1, 19-29

Hurst, M.E.E. (1985) Geography has neither existence nor future. in R.J. Johnston (Ed.) The Future of Geography London. Methuen (pp.59-91)

Law, J. 2006. Big Pharma. How the world's biggest drug companies control illness. London. Constable

Lym, G. 1980. A Psychology Of Building. How we shape and experience our structured spaces. New Jersey. Prentice-Hall

Martin, G. and Wheeler, K. (Eds.) (1975) Insights Into Environmental Education.

67 Journal of Practice Teaching \& Learning 7(2) 2006-07, pp.55-68. ( 2007 Whiting \& Birch Ltd 
Edinburgh: Oliver and Boyd

Massey, D. and Jess, P. (Eds.) (1995) A Place In The World? Places, cultures and globalization. Milton Keynes: The Open University

Oliver, M. and Sapey, B. (1999) Social Work With Disabled People. (2nd ed.) London: Macmillan

Paasi, A. (1991) Deconstructing regions: Notes on the scales of spatial life. Environment and Planning A, 23, 2, 239-256

Peet, R. and Thrift, N. (Eds.) (1989) New Models in Geography. Vol.2. London: Unwin Hyman

Phillipson, C. (2007) The 'elected' and the 'excluded': Sociological perspectives on the experience of place and community in old age. Ageing and Society, 27, 321-342

Phillipson, C. (1989) Developing a political economy of drugs and older people. Ageing and Society, 9, 4, 431-440

Plant, B. and McFeely, S. 2004. Working With Young People: Real stuff. Salisbury. AP

Popay, J., Thomas, C., Williams, G., Bennett, S., Gatrell, A., and Bostock, L. (2003) A proper place to live: Health inequalities, agency and the normative dimensions of space. Social Science and Medicine, 57, 55-69

Sommer, R. (1974) Tight Spaces. Hard architecture and how to humanize it. New Jersey: Prentice-Hall

Stea, D.(1976). Environmental Mapping. Milton Keynes: Open University Press

Urry, J. (1985) Social relations, space and time. in D. Gregory and J. Urry (Eds.) Social relations and spatial structures. Basingstoke: Macmillan

Ward, C.(ed).1973. Vandalism. London: The Architects' Press

Wilkinson, P. and Bissell, G. (2005) The 'Place' of placements. Practice, 17, 4, 285-298 